\title{
ANALISIS PERBANDINGAN JUMLAH PENERIMAAN CHT DALAM PERSPEKTIF ISLAM DAN REALITA SEBELUM DAN SAAT PANDEMI
}

\author{
Fatmawati Zahroh \\ UIN Maulana Malik Ibrahim Malang \\ Email: fatmawati.zahroh.fe@uin-malang.ac.id
}

\begin{abstract}
Excise becomes one of these income items from the Customs and Excise sector, and almost 95\% of customs receipts come from Tobacco Proceeds Excise (CHT). This research will compare CHT revenues, especially now in pandemic times, that significantly affect the economy in all sectors, no exception to the cigarette business. And the result is a decrease in each month compared, and only in August 2020 experienced positive growth. Simultaneously, the quantitative test is difference showed a significance level of 0.237, which means that there is no significant difference in CHT between before and during the pandemic. However, the realization of CHT's revenue in August 2020 increased even though it was not very much 0.187 compared to cht revenue in August 2019. Conclusion This study produced no significant difference in regulating taxes on cigarette excise did not affect cigarette consumption. Consumers of cigarettes have no effect on their consumption activities on cigarettes.
\end{abstract}

Keyword: Tobacco Excise Duty (CHT); Islamic Perspectives; Covid-19 pandemic.

\begin{abstract}
Abstrak
Cukai menjadi salah satu item yang paling besar pendapatannya dari sektor Bea dan Cukai dan hampir 95\% dari penerimaan Bea dan cukai berasal dari Cukai Hasil Tembakau (CHT). Penelitian ini akan membandingkan pendapatan CHT apalagi sekarang di saat pandemi yang sangat mempengaruhi perekonomian di segala sektor tak terkecuali bisnis rokok. Dan hasilnya terjadi penurunan di setiap bulan yang dibandingkan dan hanya pada Agustus 2020 mengalami pertumbuhan positif. Sedangkan metode penelitiannya kuantitatif uji beda memperlihatkan tingkat signifikansi 0,237 yang berarti bahwa tidak berbeda signifikan CHT antara sebelum dan saat pandemi. Akan tetapi realisasi pendapatan CHT pada saat Agustus 2020 mengalami peningkatan walau tidak terlalu banyak yaitu 0,187 dibandingkan dengan pendapatan CHT Agustus 2019. Penelitian ini yang menghasilkan tidak berbeda signifikan bahwa regulasi pajak atas cukai rokok tidak memiliki pengaruh atas konsumsi rokok. Konsumen rokok tidak berpengaruh dalam aktivitas konsumsinya terhadap rokok.
\end{abstract}

Kata Kunci: Cukai Hasil Tembakau (CHT); Perspektif Islam; Pandemi Covid-19. 


\section{Fatmawati Zahroh}

\section{PENDAHULUAN}

Undang-Undang Nomor 17 Tahun 2003 mengenai Keuangan Negara menyebutkan, bahwa pendapatan negara adalah semua pemasukan yang bersumber dari pajak, penerimaan non pajak dan menerima hibah dari dalam negeri dan luar negeri. Ini berarti, bahwa sumber pemasukan negara berasal dari 3 sektor, yaitu: pajak, non pajak dan hibah. Ketiga sektor inilah yang menjadi "tulang punggung" pendapatan negara.

Ketiga pendapatan tersebut digunakan dalam rangka mensejahterakan rakyat sebagai pengamalan sila kelima dari Pancasila, yaitu Keadilan Sosial bagi Seluruh Rakyat Indonesia. Dari sini nantinya merealisasikan diantaranya bantuan sosial, pembangunan fasilitas umum, dan kemaslahatan umum lainnya

Pajak benar-benar menjadi tumpuan pendapatan negara. Dalam APBN 2019, tercatat tidak kurang sebesar 82,5 persen dari total Pendapatan Negara berasal dari pajak, disusul berikutnya adalah Bea dan Cukai.(Nurisdiyanto, 2020) Cukai merupakan salah satu item yang paling besar pendapatannya dari sektor Bea dan Cukai, hal ini tidak aneh, mengingat Cukai Hasil Tembakau (CHT) yang merupakan bagian dari Cukai tersebut. Di Tahun 2020 ini, hampir 95\% dari total penerimaan Bea \& Cukai, berasal dari Cukai Hasil Tembakau (CHT), tak ayal, CHT menjadi andalan dan tulang punggung pemerintah di sektor Bea dan Cukai (Antonius, 2019).

CHT menjadi salah satu cukai yang memberikan kontribusi terbesar bagi penerimaan Negara setiap tahunnya. Berdasarkan data yang diperoleh dari data Perkembangan Realisasi Pencapaian Target Pemerimaan KPPBC Tipe Madya Cukai Malang diketahui bahwa pemerimaan Cukai Hasil Tembakau beberapa tahun terakhir selalu naik dan mencapai target. Di tahun 2017 realisasi pemerimaan cukai melampaui targer sebesar 18,53 Triliun atau 100,27\%. Pada tahun 2018 dan 2019 juga terjadi hal yang sama, masing-masing sebesar 20,1
Triliun atau $103,68 \%$ dan 20,91 Triliun atau $101,28 \%$.

\author{
Gambar 1 Realisasi Total \\ Penerimaan KPPBC Tipe Madya \\ Cukai Malang
}

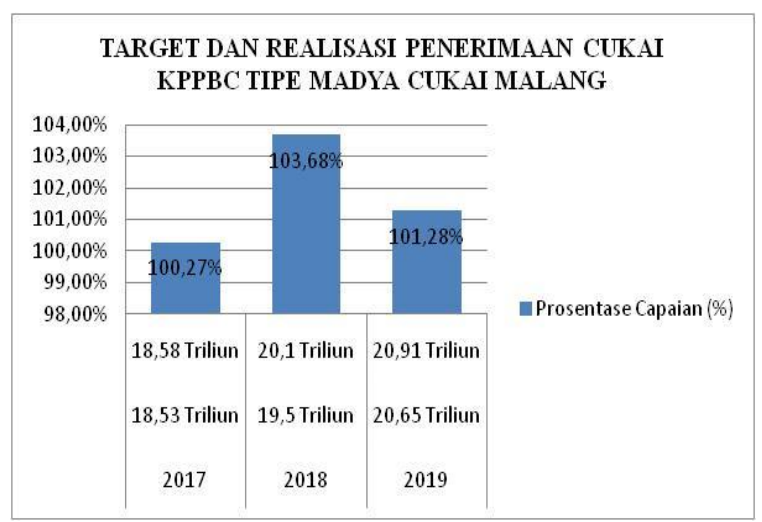

Sumber : Data Perkembangan

Realisasi Pencapaian Target

Pemerimaan KPPBC Tipe Madya

Cukai Malang

Periode 2017 s/d 2019

Dilansir di (Databoxs, 2016) Indonesia menduduki peringkat tertinggi se Asean dalam konsumsi rokok perkapita per tahunnya. Sedangkan data dari tobaccoatlas.org, disebutkan, Indonesia di tahun 2014, konsumen rokok pada usia 15 tahun ke atas dilansir $1.322,3$ batang perkapita per tahunnya, disusul Filipina peringkat kedua dengan mengkonsumsi rokok sebesar 1.291,08 batang per kapita per tahunnya, dan di peringkat ketiga ditempati Vietnam dengan mengkonsumsi rokok mencapai 1.215,3 batang perkapita per tahun.

Penerapan sin tax dalam Cukai Hasil Tembakau, selain memberlakukan PPN kepada wajib pajak kepada pihak yang terkait, juga mengakibatkan harga rokok menjadi tinggi sehingga dapat mengurangi jumlah konsumen rokok. Kebijakan ini sama seperti konsep pajak dan tembakau yang disampaikan oleh (Laffer, 2014) yakni cukai ialah pajak yang dikenakan pada barang konsumtif dan spesifik, seperti alkohol, bensin, atau tembakau, dan ditujukan pada system dan mekanisme yang memperoleh 


\section{Fatmawati Zahroh}

penerimaan negara secara keseluruhan, serta ditujukan untuk mengurangi konsumen rokok.

Namun, pada kenyataannya, di Indonesia justru tidak memberikan dampak yang diharapkan. Harga yang terbentuk dari regulasi tersebut pada rokok belumlah meredupkan keinginan rakyat Indonesia dalam konsumsi rokok, walaupun pada faktanya harga rokok terus-menerus melambung. Terlihat dari adanya pendapatan Cukai Hasil Tembakau yang relatif melonjak dan bahkan melewati target seperti yang digambarkan pada gambar 1.1.

Fenomena ini membuktikan adanya peningkatan tarif Cukai Hasil Tembakau, memberi efek menekan terhadap jumlah pengusaha rokok. Tergerusnya populasi pengusaha rokok menyebabkan penerimaan Cukai Hasil Tembakau mengalami penurunan.

Besarnya penerimaan CHT dikarenakan adanya kenaikan tarif cukai yang dilakukan setiap tahunnya oleh pemerintah. Berdasarkan Peraturan Menteri Keuangan Nomor (PMK) 152/PMK.010/2019 tentang amandemen kedua atas PMK Nomor 146/PMK.010/2017 tentang Perubahan Tarif Cukai Hasil Tembakau yang mulai berlaku per 1 Januari 2020 tentu memberikan pengaruh pada penerimaan cukai hasil tembakau pada tahun ini.

Selain kenaikan tarif cukai, sejak diumumkannya kasus pertama positif Corona di Indonesia oleh Presiden Joko Widodo bersama Menteri Kesehatan Terawan Agus Purnomo pada 2 Maret 2020 disusul Keputusan Presiden (Kepres) Nomor 12 Tahun 2020 tentang Penetapan Bencana Non-Alam Penyebaran Corona Virus Disease 2019 (COVID-19) yang ditandatangini pada 13 April 2020 juga menjadi salah satu faktor yang diteliti pada penelitian ini (Kepres Bencana Non-Alam, 2020). Wabah Pandemi Covid-19 sejak Februari atau Maret 2020 yang terjadi di Indonesia ini, memberikan dampak pada perekonomian rakyat, tentu secara logika akan memberikan pengaruh juga terhadap pendapatan negara, khususnya sektor pajak dan bea cukai, Untuk itu, perlu dilakukan analisis tertentu untuk mengetahui sejauh mana, atau sebesar apa penerimaannya.

Jika dalam perspektif Islam, cukai disebut sebagai usyur yang dipungut dari pihak terpungut oleh pemungut. Pada zaman khalifah Umar kegiatan perdagangan sangat sering dan popular. Ada 3 kelompok pedagang:

1. Pedagang muslim, tidak boleh dipungut usyur Nabi SAW bersabda,

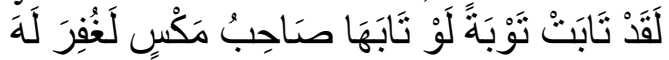

"Sesungguhnya dia telah bertaubat, yang jika petugas pajak bertaubat sepertinya niscaya dia akan diampuni oleh Allah". Dalam hadis lain disebutkan,

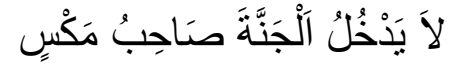

"Tidak masuk surga petugas pajak".

Di mana ulama menafsirkan bahwa petugas pajak ini adalah "Orang yang mengambil 'usyūr dari harta kaum Muslimin.

2. Pedagang Ahlu Dzimmah, ada perbedaan pendapat antar ulama, ada yang menyebutkan tidak diperbolehkannya dipungut usyur dan ada yang membolehkan.

3. Pedagang Ahlu Harb, diperbolehkan memungut usyur sebesar 10\%. (Ibnu Ahmad al-Haris, 2006)

Demikianlah sejarah menyebutkan bahwa telah adanya aktivitas perdagangan pada masa pemerintahan Islam terdahulu.

Dari pemaparan secara realita di Indonesia dan sejarah pada masa kekhalifahan Umar, penelitian ini hanya menunjukkan realita pada pendapatan negara yang dihasilkan dari salah satu Cukai, yaitu Cukai Hasil Pertanian (CHT) di Malang Raya dengan bulan yang sama di tahun yang berbeda untuk di analisis apakah di masa pandemi Covid-19 dan adanya kenaikan tarif untuk cukai hasil pertanian, berpengaruh besar terhadap penerimaan dari CHT tersebut. Meliputi masalah: 1) Kebijakan 
kenaikan tarif; 2) Dampak kenaikan tarif dengan hasil uji beda; 3) Respon masyarakat; 4) Perbandingan cukai di masa Islam (dalam pemerintahan khalifah Umar bin Khattab).

\section{LITERATURE REVIEW}

Pemerintah memberlakukan berbagai macam pajak atas tembakau dan produk tembakau. Beberapa berlaku untuk tembakau daun, seperti pajak atas nilai tanaman tembakau dan bea atas impor dan / atau ekspor daun tembakau. Sebagian besar pemerintah menilai pajak atas produk tembakau. Pajakpajak tersebut meliputi: pajak cukai, pajak pertambahan nilai (PPN), pajak penjualan umum, bea tembakau impor produk dan / atau ekspor dan / atau pajak khusus lainnya. Dari ini, pajak cukai hasil tembakau (termasuk pajak lainnya khusus diterapkan pada produk tembakau tetapi disebut dengan yang lain nama) paling penting untuk mencapai tujuan kesehatan mengurangi konsumsi tembakau karena ini adalah pajak yang berlaku diterapkan secara unik pada produk tembakau dan yang menaikkan harga produk ini relatif terhadap harga barang dan jasa lainnya (WHO, 2010).

Pada 2018, pendapatan CHT tidak kurang dari Rp 152,9 triliun atau secara persentase senilai $95,8 \%$ dari seluruh penerimaan cukai yang senilai Rp 159,6 triliun. Angka pemasukan CHT pada 2018 mengalami peningkatan 3,5\% daripada tahun lalu yang senilai Rp 147,7 triliun. Di tahun 2019, diprediksikan pendapatan CHT mengalami peningkatan 3,9\% ke Rp 158,9 triliun (Databoks, 2019).

Sedangkan, pada RAPBN (Rancangan Anggaran Pendapatan dan Belanja Negara) 2020, penargetan pendapatan CHT meningkat menjadi Rp 171,9 triliun atau meningkat sampai $8,2 \%$. Hal ini adalah target paling tinggi jika membandingkannya dengan tahun-tahun yang lalu. Oleh karenanya, pemerintah memberi ketetapan peningkatan cukai rokok menjadi $23 \%$ dan harga ecer $35 \%$. Naiknya cukai tersebut berlaku mulai 1 Januari 2020 (Databoks, 2019).
Kenaikan tarif CHT (Cukai Hasil Tembakau) berkontribusi secara signifikan. Dibuktikan di tahun 2013 sampai 2016, pendapatan cukai selalu mengalami kenaikan dan berkontribusi cukup berarti yaitu dari hasil tembakau jenis SKM, SKP, dan SPM. Ternyata tiap tahunnya pendapatan tersebut mengalami kenaikan, walaupun Direktur Jenderal Bea dan Cukai harus mengalami kendala demi kendala yang harus dilalui. Informasi tersebut menjadi bukti, bahwa DirJen Bea dan Cukai mampu mendapatkan salah satu alasan pemberlakuan cukai, yaitu sebagai pemasukan negara (Triono, 2017). (Alkausar, 2015; A. M. Dian. Sari, 2016) dalam penelitiannya bahwa regulasi pajak pada rokok tidak memberi efek pada pemakaian rokok. Berbeda dengan penelitian (Alkausar, 2015; A. M. Dian. Sari, 2016), hasil penelitian (Romadhon \& al Musadieq, 2016) menyebutkan ada pengurangan jumlah pengusaha rokok sebagai akibat dari kenaikan tarif CHT. Dengan berkurangnya industri rokok berakibat turunnya pendapatan CHT.

Senada dengan pemaparan (Canada, 2012; Romadhon \& al Musadieq, 2016) memaparkan proporsi laba perusahaan rokok dan pendapatan pajak negara atas rokok secara kontinyu sebagai dampak adanya kenaikan pajak atas rokok secara terus menerus. Hal ini juga singkron dengan penelitian rancangan tarif (Adiatma, 2010) yang berpendapat tentang subskenario tambahan tarif cukai, yakni seiring dengan besarnya tarif cukai yang dikenakan maka industri rokok akan mengalami penurunan akumulasi laba. Peningkatan tembakau yang signifikan pajak adalah strategi pengendalian tembakau yang sangat efektif dan mengarah pada peningkatan yang signifikan dalam kesehatan masyarakat (Chaloupka et al., 2011). pajak harus adil dan selaras dengan spirit Islam yaitu sesuai dengan maqasid Syariah.

\section{METODE PENELITIAN}

Metode penelitian yang digunakan adalah metode kuantitatif yaitu pemrosesan dan 
manipulasi data mentah mengenai informasi yang bermanfaat. Pengujian hipotesis dalam penelitian ini di tentukan berdasarkan hasil dari uji normalitas data, berdasarkan hasil uji normalitas data maka akan dapat ditentukan alat uji apa yang paling sesuai digunakan. Apabila data berdistribusi normal maka digunakan uji parametrik Paired Sample TTest. Sementara apabila data berdistribusi tidak normal maka digunakan uji nonparametrik yaitu Wilcoxon Signed Rank Test. Kedua model uji beda tersebut digunakan untuk menganalisis model penelitian pre-post atau sebelum dan sesudah. Uji beda digunakan untuk mengevaluasi perlakuan (treatment) tertentu pada satu sampel yang sama pada dua periode pengamatan yang berbeda (Pramana \& Mawardi, 2012). Dan dalam penelitian ini menggunakan metode uji parametrik Paired Sample T-Test karena memiliki data berdistribusi normal.

\section{Pengambilan Data dan Sampel}

Penelitian ini menguji dua sampel yang berpasangan. Uji beda t-test untuk menggambarkan ada tidaknya perbedaan yang signifikan rata-rata jumlah pendapatan CHT sebelum dan setelah kenaikan tarif di saat terjadinya pandemi covid-19 dari sebelumnya menggunakan Peraturan Menteri Keuangan Nomor 146/PMK.010/2017 menjadi Peraturan Menteri Keuangan Nomor 152/PMK.010/2019 . Hasil uji beda t-test apabila $\alpha \mathrm{P}$ - value $>0,05$ maka $\mathrm{H}_{\mathrm{a}}$ ditolak, dan jika $\alpha \mathrm{P}$ - value $<0,05$ maka $\mathrm{H}_{\mathrm{a}}$ diterima.

Adapun data yang dipakai adalah data sekunder yang diambil data realisasi penerimaan CHT di bulan Maret s.d Agustus 2019 (sebelum pademi) dan data realisasi penerimaan CHT bulan Maret s.d Agustus 2020 (saat pandemi). Pengambilan data dengan purposive sampling hanya di bulan Maret s.d Agustus 2019 dan Maret s.d Agustus 2020 dimaksudkan untuk membandingkan penerimaan CHT di tahun berbeda dan kondisi berbeda yaitu sebelum pandemi dan saat pandemi, dengan membandingkan bulan yang sama diharapkan dapat menghasilkan uji beda yang seimbang dengan artian bahwa dengan bulan yang sama dimaksudkan dengan musim yang sama yang diujibedakan dikenal dengan istilah "apple to apple" yang bermakna perbandingan yang proporsional. Oleh karena itu penulis tidak menngunakan data periode September-Februari 2019 (enam bulan sebelum adanya pandemi covid-19) dan periode Maret-Agustus 2020 (lima bulan setelah adanya pandemi covid-19) dikarenakan perbandingan data tersebut tidak seimbang dan tidak proporsional atau dikenal dengan istilah "apple to orange". Istilah-istiah tersebut biasa digunakan dalam dunia bisnis dan ekonomi untuk membandingkan produk yang sejenis secara terperinci dari semua aspek.

Berdasarkan Data Perkembangan Realisasi Pencapaian Target Penerimaan Cukai Hasil Tembakau (CHT) KPPBC Tipe Madya Cukai Malang Periode 2018, 2019 s/d 2020 didapat sebagai berikut:

Tabel 1 Realisasi Penerimaan CHT

\begin{tabular}{lll}
\hline No & Periode & $\begin{array}{c}\text { Realisasi } \\
\text { Penerimaan CHT }\end{array}$ \\
\hline 1 & Maret 2018 & 1.304 .862 .975 .800 \\
\hline 2 & April 2018 & 1.633 .063 .628 .600 \\
\hline 3 & Mei 2018 & 1.880 .816 .738 .760 \\
\hline 4 & Juni 2018 & 1.405 .619 .288 .400 \\
\hline 5 & Juli 2018 & 2.234 .964 .210 .000 \\
\hline 6 & Agustus & $1,245,039,209,000$ \\
& 2018 & \\
\hline 7 & Maret 2019 & 1.374 .931 .403 .000 \\
\hline 8 & April 2019 & 1.955 .764 .503 .824 \\
\hline 9 & Mei 2019 & 2.461 .442 .570 .400 \\
\hline 10 & Juni 2019 & 1.324 .335 .692 .080 \\
\hline 11 & Juli 2019 & 1.761 .130 .220 .820 \\
\hline 12 & Agustus & $1,155,494,338,800$ \\
& 2019 & \\
\hline 13 & Maret 2020 & 990.735 .171 .000 \\
\hline 14 & April 2020 & 1.551 .170 .542 .990 \\
\hline 15 & Mei 2020 & 2.200 .799 .380 .050 \\
\hline & & \\
\hline
\end{tabular}




\begin{tabular}{lll}
\hline 16 & Juni 2020 & 1.104 .959 .731 .800 \\
\hline 17 & Juli 2020 & 1.265 .112 .747 .040 \\
\hline 18 & Agustus & $1,371,799,340,120$ \\
& 2020 & \\
\hline & Sumber : Data Realisasi Penerimaan \\
& CHT KPPBC Tipe Madya Cukai \\
& \multicolumn{2}{c}{ Malang } \\
& Periode 2018 s/d 2020
\end{tabular}

\section{Uji Beda T-Test dengan Sampel Berpasangan}

a. Rasio Pertumbuhan

Penghitungan rasio pertumbuhan adalah untuk melihat kinerja pemerintah dalam meraih target yang sudah diraihnya dari periode sekarang ke periode selanjutnya, berikut rumus dari rasio pertumbuhan:

$$
\begin{aligned}
& \text { Rasio Pertumbuhan } \\
& =\frac{\text { Penerimaan } t-\text { Penerimaan } t-1}{\text { Penerimaan } t-1}
\end{aligned}
$$

Keterangan :

Penerimaan $\mathrm{t}=$ penerimaan periode saat ini Penerimaan $\mathrm{t}-1=$ penerimaan periode sebelumnya

\section{b. Uji Beda t-test}

Menurut (D. P. Sari, 2019) uji beda ttest dilakukan dalam uji beda ratarata dua sampel yang berhubungan. Sampel yang berpasangan adalah suatu bahan penelitian yang sama namun mendapat dua value atau treatment yang berbeda (Lupiyoadi \& Ikhsan, 2015).

\section{KONSEP DASAR \\ Cukai dalam Perspektif Islam}

Bea cukai dalam Bahasa arab disebut AlUsyur, Al-Maks atau Ad-Dharibah yang memiliki arti pungutan dari rakyat oleh penarik pajak. Berdasarkan hasil diskusi Departemen Keilmuan dan Kajian Intelektual SEF UGM, ada dua jenis pajak dalam Islam, yaitu pajak rustum dan pajak mukus.Pajak rustum merupakan pajak yang dibayarkan oleh warga negara atas fasilitas yang disediakan oleh pemerintah seperti pajak bandara atau pajak jalan. Sedangkan pajak mucus yang dikenakan kepada warga negara karena mereka tinggal di wilayah negara tersebut (SEF, 2017).

Umar RA menentukan pedagang yang di ambil 'usyūr, di mana Ziyad bin Hudair meriwayatkan, "Bahwa Umar bin AlKhattab mengutusnya dalam masalah 'usyūr ke Irak dan Syam, dan memerintahkannya untuk mengambil $2.5 \%$ dari kaum Muslim, $5 \%$ dari kaum Zhimmi, dan $10 \%$ dari kafir Harbi" (Ibnu Ahmad al-Haris, 2006).

Dari riwayat tersebut dapat dibedakan antara tiga kelompok pedagang yaitu pedagang Muslim, pedagang dari kalangan ahlu Zhimmah, dan pedagang dari kelompok ahlu Harbi. Dimana hakikat yang di ambil dari masing-masing kelompok dapat dijelaskan sebagai berikut pertama: Pedagang Muslim Terdapat beberapa hadis yang menunjukkan tidak bolehnya pengambilan 'usyūr dari pedagang muslim lalu Nabi SAW bersabda,

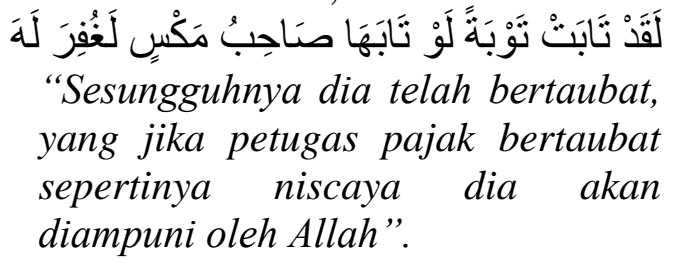

Dalam hadis lain disebutkan,

$$
\text { لاَ يَخْخُلْ آلَجَنَّةَة صَاحِبُ مَكْسِ }
$$

“Tidak masuk surga petugas pajak”.

Di mana ulama menafsirkan bahwa petugas pajak ini adalah "Orang yang mengambil 'usyūr dari harta kaum Muslimin; di mana ia mengambil secara paksa dari pedagang Muslim jika melintasi daerahnya dengan mengatasnamakan ' $u s y \bar{u} r$, dan bukan petugas yang mengumpulkan zakat.

Adapun 'usyūr yang di ambil dengan kesepakatan dari dagangan orang-orang yang memiliki perjanjian dagang dengan negara Islam, maka itu bukanlah bentuk pemaksaan, dan petugasnya tidak berhak mendapatkan ancaman tersebut; kecuali jika dia melampaui batas dan zalim, maka dikhawatirkan dosa dan sanksi baginya”. 


\section{Fatmawati Zahroh}

Sebagaimana juga terdapat beberapa riwayat yang menunjukkan dilarangnya mengambil 'usyūr dari seorang muslim dan kafir Zhimmi, diantaranya adalah perkataan Ziyad bin Hudair kepada Umar RA, "Kami dahulu tidak mengambil 'usyūr dari seorang muslim ataupun kafir Zhimmi". Umar berkata, "Lalu siapa yang kamu ambil 'usyūr-nya?" Ia menjawab, "Para pedagang dari ahlu Harbi, sebagaimana mereka mengambil 'usyūr kepada kami jika kami datang ke negeri mereka". Dalam riwayat lain Ziyad berkata, "Dan dia melarangku mengambil 'usyūr kepada seorang Muslim, atau kafir Zhimmi yang menyerahkan kharāj"'.

Hal ini karena seorang muslim tidak diwajibkan membayar 'usyūr, dan tidak wajib pula membayar bea cukai atas barang dagangannya, kecuali membayar zakat, berupa $1 / 4$ ' usyūr atau $2.5 \%$. Dan ini bukanlah pajak atau 'usyūr penuh. Dengan demikian, jelas bahwa maksud dari hadis Ibnu Umar dan hadis Ziyad bin Hudair, bahwa Umar tidak memungut 'usyūr melainkan memungut zakat dagang dari kaum Muslim, dengan ketentuan 1/4 'usyūr bukan 'usyūr penuh.

Kedua, Pedagang Ahlu Zhimmah. Para ulama berbeda pendapat dalam hal ini, di mana ulama Syafi'iyah dan Ibnu Hazm berpendapat tentang haramnya pengambilan 'usyūr dari harta ahlu Zhimmah, selama tidak dipersyaratkan kepada mereka dalam akad perdamaian. Namun, ulama Syafi'iyah mengecualikan daerah Hijaz, di mana mereka memperbolehkan pengambilan 'usyür dari dagangan ahlu Zhimmah yang masuk daerah Hijaz dengan membawa dagangan.

Madzhab Maliki berpendapat diperbolehkannya pengambilan 'usyūr terhadap dagangan kafir Zhimmi jika ia membawa dagangannya melewati batas daerah mukimnya. Tapi, jika ia berdagang di daerahnya, maka tidak ada kewajiban apapun terhadapnya. Sebagai contoh jika seorang kafir Zhimmi termasuk penduduk Syam, maka tiada wajib 'usyūr baginya jika ia berdagang dalam batas-batas daerah Syam. Tapi, jika keluar dengan dagangannya ke Mesir atau ke Irak maka di ambil 'usyūr darinya.

Ulama Hanafi dan ulama Hambali berpendapat diperbolehkannya pengambilan 'usyūr dari para pedagang ahlu Zhimmah secara mutlak, baik dia berdagang di daerah tinggalnya sendiri atau membawa dagangannya dari suatu daerah ke daerah lain. Adapun beberapa riwayat yang menunjukkan larangan pengambilan 'usyūr dari pedangang Muslim dan pedagang kafir Z|immi, maka Abu Ubaid berpendapat bahwa beberapa riwayat itu berarti bahwa mereka tidak di ambil 'usyūr secara penuh (10\%) sebagaimana yang di ambil dari ahlu Harbi. Namun, dari pedagang Muslim hanya seperempat dari $10 \%(2.5 \%)$, sedangkan dari ahlu Zhimmah setengah dari 10\% (5\%). (Ibnu Ahmad al-Haris, 2006)

Ketiga, Pedagang Ahlu Harbi. Hukum yang asal bagi para pedagang ahlu Harbi yang masuk ke wilayah kaum Muslimin untuk berdagang adalah di ambil pajak 10\% dari mereka; karena mereka mengambil 10\% dari para pedagang Muslim jika masuk ke daerah mereka untuk berdagang, sehingga Umar memerintahkan untuk memperlakukan hal yang sama terhadap para pedagang ahlu Harbi. Sebagaimana sebagian pedagang ahlu Harbi juga meminta dari kaum Muslimin agar diizinkan masuk ke wilayah Islam untuk berdagang dengan imbalan 10\%, maka Umar pun mengizinkan mereka setelah bermusyawarah dengan kaum Muslimin dan konsensus dalam hal tersebut.

Adapun barang yang terkena usyur adalah perhiasan, hewan, hasil pertanian, atau buah-buahan. Waktu pemungutan usyur adalah dipungut satu kali dalam setahun untuk satu jenis barang dagangan, walaupun pedagang tersebut berkali-kali melewati perbatasan dengan barang dagangannya itu.

Dalam penelitian (Rusmahafi, 2011) bahwa ekonomi Islam sangat menganjurkan perdagangan sebagai tulang punggung perekonomian dengan melaksanakan 
kegiatan ekspor dan impor. Di Arab Saudi telah melaksanakan mengaplikasikan anjuran menurut agama, sedangkan di Indonesia masih berkomoditi migas bukan pertanian. Dan menurut (Kholis, 2010)

\section{PEMBAHASAN DAN DISKUSI}

\section{Rasio Pertumbuhan}

Rasio pertumbuhan digunakan untuk melihat kinerja pemerintah dalam mencapai target yang telah diraihnya dari periode sekarang ke periode selanjutnya. Dalam hal ini analisis rasio pertumbuhan penerimaan CHT sebelum dan sesudah kebijakan tarif baru yang berlaku saat terjadinya pandemi covid-19, dapat dilihat pada tabel berikut:

Tabel 3 Rasio Pertumbuhan

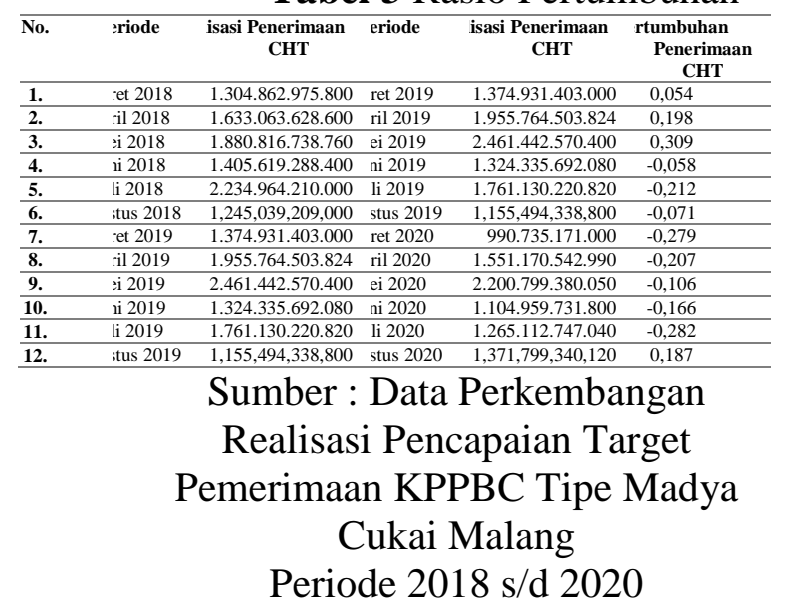

Rasio pertumbuhan di atas menunjukkan perbandingan antara tahun yang sama-sama belum mengalami pandemi yaitu di tahun 2018 dan 2019 mulai mengalami penurunan pada bulan Juni yaitu sebesar $-0,058$ dan terus mengalami penurunan hingga sekarang. Sedangkan perbandingan masa tahun sebelum dan saat pandemi yaitu tahun 2019 dan 2020 mengalami penurunan terparah pada bulan Juli yaitu sebesar 0,282 . Dan mengalami kenaikan pada Agustus 2020.

\section{Analisis Data}

Analisis data realisasi penerimaan CHT menggunakan uji statistik parametrik Repeated ANOVA. Dalam perhitungan hasil penelitian ini digunakan taraf kepercayaan 95\% $(\alpha=$ 0,05). Repeated ANOVA dapat dilakukan jika data memenuhi asumsi kenormalan data oleh karena itu terlebih dahulu dilakukan uji normalitas data dengan menggunakan metode Saphiro - Wilk test. Metode ini digunakan untuk menganalisis apakah data tersebut mempunyai distribusi secara normal atau tidak yang dikhususkan untuk sampel kecil.

Tabel 2 Hasil Uji Normalitas

\begin{tabular}{ccc}
\hline Variabel & Koefisien SW & P-value \\
\hline $\begin{array}{c}\text { Realisasi CHT } \\
\mathbf{2 0 1 8}\end{array}$ & 0.914 & 0.466 \\
\hline $\begin{array}{c}\text { Realisasi CHT } \\
\text { 2019 }\end{array}$ & 0.930 & 0.581 \\
\hline $\begin{array}{c}\text { Realisasi CHT } \\
\text { 2020 }\end{array}$ & 0.890 & 0.316 \\
\hline
\end{tabular}

Sumber: Hasil Uji Normalitas

Uji normalitas data realisasi CHT dapat dilihat pada tabel 4.1. Hipotesis dari data ditentukan melalui nilai signifikansi yang diperoleh, dimana $\mathrm{H}_{0}$ adalah data berdistribusi normal. $\mathrm{H}_{0}$ ditolak bila nilai $\mathrm{p}$ value $<\alpha(5 \%)$. Berdasarkan hasil analisis dapat diperoleh bahwa untuk keseluruhan data realisasi CHT pada tahun 2018, 2019, dan 2020 nilai p-value didapatkan lebih besar daripada $\alpha \quad(5 \%)$ sehingga dapat dinyatakan bahwa $\mathrm{H}_{0}$ diterima yang bermakna bahwa data realisasi CHT berdistribusi normal.

Distribusi data CHT yang telah ditemukan normal dalam penelitian ini maka pengujian Repeated ANOVA dapat dilakukan Hasil uji Repeated ANOVA dapat dilihat pada tabel 4.2 
Tabel 3. Hasil Pengujian Repeated ANOVA

\begin{tabular}{|c|c|c|c|}
\hline $\begin{array}{c}\text { Realisasi } \\
\text { CHT }\end{array}$ & Mean +/- SD & p-value & Ket. \\
\hline 2018 & $\begin{array}{c}16173943420 \\
00+/- \\
38267539790 \\
0\end{array}$ & 0.237 & $\begin{array}{c}\text { Tidak } \\
\text { Berbeda } \\
\text { Nyata }\end{array}$ \\
\hline 2019 & $\begin{array}{c}16721831210 \\
00+/- \\
48735699050 \\
0.00000\end{array}$ & & \\
\hline 2020 & $\begin{array}{c}14140961520 \\
00+/- \\
43277621920 \\
0\end{array}$ & & \\
\hline
\end{tabular}

Berdasarkan tabel 4.3 didapatkan nilai p-value sebesar 0.237 yang lebih besar dari nilai $\alpha(5 \%)$, sehingga dapat dikatakan bahwa tidak terdapat perbedaan yang signifikan realisasi CHT pada tahun 2018, 2019, dan 2020. Gambaran kondisi realisasi CHT pada saat kondisi tahun 2018, 2019, dan 2020 dapat dilihat pada Gambar 2.

Gambar 2 Grafik Realisasi CHT tahun 2018, 2019, dan 2020

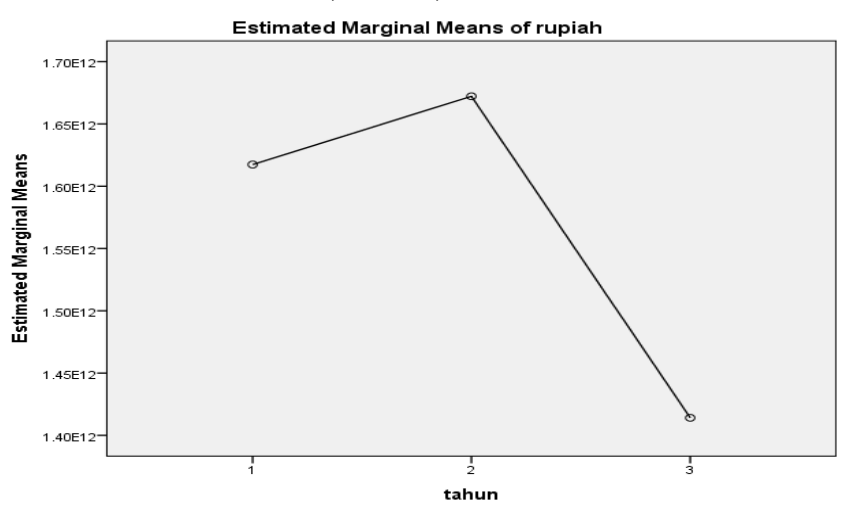

Sumber : Data Realisasi Pencapaian Target Pemerimaan KPPBC Tipe Madya Cukai Malang tahun 20182020

Keterangan :

$1=$ Tahun 2018

$2=$ Tahun 2019

$3=$ Tahun 2020
Grafik realisasi CHT pada gambar 4.1 menunjukkan bahwa realisasi CHT pada tahun 2019 mengalami kenaikan dibandingkan tahun 2018 dan mengalami penurunan pada tahun 2020. Penurunan realisasi CHT salah satunya dapat dikarenakan kondisi pandemi COVID-19 di Indonesia, namun penurunan ini berdasarkan hasil pengujian repeated ANOVA didapatkan tidak signifikan.

Penelitian ini senada dengan penelitian (Alkausar, 2015; A. M. Dian. Sari, 2016) yang memaparkan kebijakan perpajakan terhadap rokok tidak berpengaruh terhadap konsumsi rokok. Kondisi masyarakat Indonesia yang menjadi konsumen potensial bagi para industri rokok.

Kenaikan tarif cukai hasil tembakau memberikan kontribusi yang besar bagi penerimaan melalui Dana Bagi Hasil Cukai Hasil Tembakau (DBH CHT), yang di mana dana tersebut digunakan untuk memberi manfaat bagi masyarakat dan mengurangi dampak yang diberikan (Lestari, 2010). Hal ini sesuai dengan fungsi dari lembaga bea cukai yaitu mengawasi, melayani serta memfasilitasi kegiatan perdagangan ekspor, impor dan serta cukai dan tujuan bea cukai adalah untuk mengoptimalkan penerimaan kepabean dan cukai melalui kenaikan tarif cukai.

Berdasarkan grafik di atas, perbandingan dalam pengumpulan penerimaan CHT cenderung mengalami penurunan yang di mana dapat disebabkan dari berbagai hal, diantaranya :

1. Pada periode Januari-Februari 2020 penerimaan CHT dapat mengalami peningkatan dibandingkan periode sebelumnya. Ini dikarenakan selain adanya kenaikan tarif, pengaruh kebijakan relaksasi pelunasan pemesanan pita cukai rokok kredit tahun 2019 juga menjadi penyebab lonjakan kenaikan jumlah penerimaan cukai hasil tembakau pada awal tahun ini.

2. Namun setelah munculnya pandemi covid-19 pada bulan Maret hingga saat ini membuat penerimaan $\mathrm{CHT}$ menurun 
dibandingkan periode sebelumnya. Berikut adalah beberapa penyebab menurunnya penerimaan CHT dikarenakan pandemi covid-19:

a. Menurunnya penjualan industri hasil tembakau (IHT) khususnya pada golongan sigaret kretek tangan (SKT) yang merupakan sektor padat karya dan menyerap tenaga kerja sangat tinggi. Kenaikan tarif cukai dan tekanan pandemi covid-19 sangat mengganggu ekosistem industri, saat ini utilitasi SKT menurunkan 40-50\% karena adanya pembatasan sosial berskala besar (PSBB) dan physical distancing akibatnya berpengaruh pada supply bahan baku rokok yang berujung pada konsumsi (Setiawan, 2020).

b. Akibat menurunya penjualan barang hasil tembakau, volume produksi IHT juga menurun ditambah lagi dengan biaya produksi lebih besar yang harus dikeluarkan IHT untuk menerapkan protokol kesehatan. Hal tersebut berdampak pada pembelian pita cukai oleh pelaku usaha yang merupakan sumber penerimaan CHT. Direktorat Jendral Bea dan Cukai (DJBC) Kementerian Keuangan (Kemenkeu) membenarkan kondisi IHT tengah menurun. DJBC memprediksi pemerimaan CHT 2020 hanya mencapai $\mathrm{Rp} 165$ triliun, tidak memenuhi target pemerintah sebesar Rp 173,15 triliun (Wicaksono, 2020).

c. Meskipun terjadi penurunan penerimaan CHT tahun ini dibandingkan periode sebelumnya, bea cukai tetap berusaha mengoptimalkan penerimaan agar memenuhi target APBN. Adanya kebijakan yang tertuang di Peraturan Menteri Keuangan (PMK) Nomor 30/PMK.04/2020 tentang Penundaan Pembayaran Cukai Untuk Perusahaan Pabrik Atau Importir Barang Kena Cukai yang Melaksanakan Pelunasan dengan Cara Pelekatan Pita Cukai yang mulai berlaku sejak 9 April 2020, dengan demikian produsen mendapat perpanjangan pembayaran yang awalnya dua bulan menjadi tiga bulan. Tujuan dari PMK Nomor 30/PMK.04/2020 ini adalah untuk menjaga kestabilan kas perusahaan rokok dalam menghadapi dampak ekonomi akibat pandemi covid-19 (Suryanto \& Dewi, 2020).

Menurunnya konsumsi rokok dapat dibuktikan dengan merosotnya penjualan PT HM Sampoerna Tbk. Berikut merupakan data keuangan PT HM Sampoerna Tbk berdasarkan Laporan Keuanagn semester I yang berakhir pada 30 Juni 2020 :

1. Penjualan bersih merosot 11,8 persen. Penjualan rokok turun dari Rp50,72 triliun pada semester I-2019 menjadi Rp44,73 triliun di semester I-2020.

2. Mengutip laporan keuangan di keterbukaan informasi Bursa Efek Indonesia (BEI), Jumat, 24 Juli 2020, penurunan penjualan disebabkan oleh merosotnya penjualan ekspor rokok pada periode ini hanya Rp142,67 miliar. Pada periode yang sama tahun lalu penjualan rokok ekspor mencapai Rp191,35 miliar. Selain itu, penjualan rokok lokal, sigaret kretek mesin juga turun dari Rp35,92 triliun menjadi Rp30,5 triliun.

3. Penjualan sigaret putih mesin juga mengalami penurunan dari Rp5,44 triliun menjadi Rp4,3 triliun. Sedangkan penjualan sigaret kretek tangan meningkat tipis dari Rp8,9 triliun menjadi Rp9,5 triliun. Penurunan penjualan ini berimbas pada capaian laba pada paruh pertama tahun ini yaitu hanya mencapai Rp4,88 triliun, atau turun 27,83 persen dibandingkan dengan periode yang sama tahun sebelumnya sebesar Rp6,77 triliun.

4. Pada periode ini perusahaan juga mencatat beban pokok penjualan sebesar Rp34,99 triliun. Beban penjualan sebesar Rp2,83 triliun. Beban umum dan administrasi sebesar Rp1,09 triliun dan 
beban biaya keuangan sebesar Rp22,5 miliar.

Menurut (Purwito \& Indriani, 2015) pungutan yang diperoleh dari pungutan bea masuk, cukai, PDRI merupakan sumber utama penerimaan yang di mana perlunya optimalisasi penerimaan Negara agar tercapainya fungsi budgetir serta fungsi regulerend dapat dicapai, maka pemerintah melaksanakan beberapa peraturan yang berkaitan erat dengan era globalisasi, perdagangan dan persaingan bebas. Pemungutan ini cenderung sebagai alat pengawasan dalam melaksanakan kebijakan pemerintah di bidang ekonomi, moneter dan sosial.

Menurut perspektif islam, pungutan CHT yang dilakukan atau dihimpun oleh bea cukai memberi dorongan kegiatan ekonomi, serta adanya pertumbuhan ekonomi di Indonesia. Pandangan Al-Mawardi, bahwa penerimaan pemerintah yang terdapat pada kas negara disimpan pada kolom-kolom terpisah dan dibelanjakan berdasarkan kebutuhan masing-masing (Jaelani, 2016). Maksud dari pandangan tersebut adalah ketika terdapat penerimaan yang didapat dari provinsi dimanfaatkan terlebih dahulu dalam memenuhi kewajiban pembiayaan provinsi tersebut. Apabila pengeluaran provinsi yang bersangkutan lebih kecil dari penerimaan provinsi maka pemerintah daerah harus mengembalikan kepada lembaga keuangan pusat, sedangkan jika pembiayaan local lebih besar atau melampaui dari pendapatan provinsi maka adanya kelebihan dari provinsi lain atau lembaga keuangan pusat mengalokasikan dana ke provinsi yang kekurangan dana, agar tidak terjadinya ketimpangan di dalam masyarakat.

Menurut (Jaelani, 2016) sistem pendistribusian harta yang menjadi tanggung jawab lembaga keuangan negara harus dimanfaatkan atas kondisi keuangan yang ada serta hak instansi tersebut untuk mendistribusikan sesuai dengan target yang sudah ditentukan. Hal ini selaras dengan pandangan al-mawardi, yang dimana bahwa harta yang menjadi hak dari lembaga keuangan terbagi menjadi 2, yaitu pertama aset yang disimpan dalam kas negara dengan tujuan tertentu dan aset keuangan pemerintah yang didapatkan atas macam-macam sumber dalam penerimaan negara.

Adanya keuangan negara yang diatur oleh pemerintah harus secara efisien artinya anggaran uang yang ada wajib bisa dimanfaatkan dengan sebaik mungkin agar bisa menciptakan peningkatan pelayanan atau fasilitas serta dapat memberikan kesejahteraan yang maksimal untuk keperluan masyarakat luas (Jaelani, 2016). Sehingga dari pandangan al-mawardi membolehkannya pungutan yang dihimpun bea cukai ini didasarkan untuk mewujudkan kemaslahatan negara. Berikut ini merupakan firman Allah yang berhubungan dengan diperbolehkannya melakukan pemungutan selain zakat yang digunakan untuk kemaslahatan Negara:

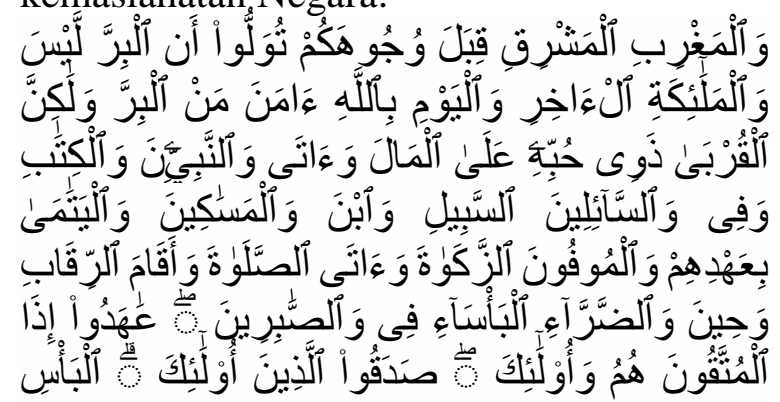

Artinya: Bukanlah menghadapkan wajahmu ke arah timur dan barat itu suatu kebajikan, akan tetapi Sesungguhnya kebajikan itu ialah beriman kepada Allah, hari Kemudian, malaikat-malaikat, kitab-kitab, nabi-nabi dan memberikan harta yang dicintainya kepada kerabatnya, anak-anak yatim, orangorang miskin, musafir (yang memerlukan pertolongan) dan orang-orang yang meminta-minta; dan (memerdekakan) hamba sahaya, mendirikan shalat, dan menunaikan zakat; dan orang-orang yang menepati janjinya apabila ia berjanji, dan orangorang yang sabar dalam kesempitan, penderitaan dan dalam peperangan. mereka Itulah orang-orang yang benar (imannya); dan mereka Itulah orang-orang yang bertakwa (QS. Al-Baqarah (2): 177). 


\section{KESIMPULAN}

Temuan dari beberapa penelitian tersebut dapat memberikan gambaran untuk mengambil kesimpulan bahwa pertama, kebijakan kenaikan tarif cukai dapat memberi dampat positif terhadap penerimaan CHT karena dapat meningkatkan jumlah penerimaan dan menaikkan rasio pertumbuhan.

Kedua, akibat adanya kenaikan tarif 2 bulan sebelum pandemi covid-19 memberi dampak negatif pada penerimaan CHT hingga saat ini dikarenakan menurunnya penjualan dan volume produksi tembakau namun bea cukai berusaha mengoptimalkan penerimaan dengan relaksasi dengan cara penundaan pembayaran pita cukai, keterlibatan komponen penerimaan CHT akan berkontribusi terhadap penerimaan pengumpulan kepabean dan cukai yang di mana untuk kepentingan masyarakat/umum.

Dan ketiga, mayoritas masyarakat Indonesia yang merupakan konsumen potensial bagi industri rokok ternyata kenaikan harga rokok akibat tarif rokok meningkat tidak merubah kebiasaan dalam mengkonsumsi rokok; 4) sedangkan dilihat dari masa lampau dalam perspektif Islam kita melihat pada masa pemerintahan Umar bin Khattab, cukai pada perdagangan dengan negara lain hanya diberlakukan $1 \mathrm{x}$ penarikan bea cukai untuk jeis pedagang ahlu zimmah dan ahlu harbi, sedangkan pedagang Islam tidak dikenakan bea cukai dalam menjual dagangannya.

\section{DAFTAR PUSTAKA}

Adiatma, P. Kristian. (2010). Analisis Pengaruh Tarif Cukai Terhadap Pendapatan Negara Dan Keberlangsungan Usaha Industri Rokok (Sebuah Pendekatan Sistem Dinamik). Surabaya: Institut Teknologi Surabaya.

Alkausar, Bani. (2015). Hubungan Penerapan Pajak Rokok Dengan Daya Beli Dan Tingkat Konsumsi Rokok (Studi Penelitian Pada
Mahasiswa Fakultas Ilmu

Administrasi Brawijaya Malang). http://repository.ub.ac.id/117746/

Antonius, Immanuel. (2019). 96 Persen Penerimaan Cukai Masih

Disumbang dari Industri Hasil

Tembakau. Liputan 6.Com. https://www.liputan6.com/bisnis/rea d/4167377/96-persen-penerimaancukai-masih-disumbang-dariindustri-hasil-tembakau

Canada, P. (2012). The Tobacco Manufacturers ' Surtax 1994 - 2012 Impact Of Corporate Income Tax Reductions And Industry Relocation. Www.Smoke-Free.Ca

Chaloupka, F. J., Straif, K., \& Leon, M. E. (2011). Effectiveness of tax and price policies in tobacco control. Tobacco Control, 20(3), 235-238. https://doi.org/10.1136/tc.2010.0399 82

Databoks. (2019). tren kontribusi cukai hasil tembakau terhadap penerimaan negara.

https://databoks.katadata.co.id/datap ublish/2019/09/16/tren-kontribusicukai-hasil-tembakau-terhadappenerimaan-negara

Databoxs. (2016). Konsumsi Rokok Per Kapita Indonesia Tertinggi Di Asean. http://databoks.katadata.co.id/Datapu blish/2016/08/31/Konsumsi-RokokPer-Kapita-Indonesia-Tertinggi-DiAsean

Ibnu Ahmad al-Haris, J. (2006). Fikih Ekonomi Umar bin Al-Khattab, Terj. Asmuni Solihan Zamakhsyari. Jakarta: Kholifa.

Jaelani, Aan. (2016). ISLAM PUBLIC FINANCES: Reflections on the APBN and the Budget Politics in Indonesia (Issue 69555). Cirebon: Nurjati Press.

Kholis, Nur. (2010). Perpajakan di Indonesia dalam Perspektif Hukum Ekonomi Islam. Jurnal Ekonomi Malaysia, 5.

Laffer, A. B. (2014). Handbook of Tobacco Taxation: Theory And 
Practice. San Fransisco: Laffer Center.

Lestari, P. (2010). Kenaikan Tarif Cukai Hasil Tembakau Sebagai Upaya Pemerintah Dalam Pencapaian Target Penerimaan Cukai Negara Di Wilayah Surakarta. 1-86.

Lupiyoadi, Rambat., \& Ikhsan, R. Bramulya. (2015). Praktikum Metode Riset Bisnis. Jakarta: Salemba Empat. Nurisdiyanto, W. Eka. (2020). betapa krusialnya pajak dalam portal kehidupan berbangsa dan bernegara. Pajak.Go.Id.

https://www.pajak.go.id/id/artikel/be tapa-krusialnya-pajak-dalam-portalkehidupan-berbangsa-dan-bernegara

Pramana, A., \& Mawardi, W. (2012). Analisis Perbandingan Trading Volume Activity dan Abnormal Return Saham Sebelum dan Sesudah Pemecahan Saham. Diponegoro Journal Management, Volume 1(1), $1-9$.

Purwito, A., \& Indriani. (2015). Ekspor,Impor, Sistem Harmonisasi, Nilai Pabean, dan Pajak Dalam Kepabeanan. Bogor: Mitra Wacana Media.

Romadhon, Masgirang., \& al Musadieq, Mochammad. (2016). Evaluasi Pemungutan Cukai Hasil Tembakau di Kantor Pelayanan dan Pengawasan Bea dan Cukai Tipe Madya Cukai Malang. Jurnal Perpajakan (JEJAK), $8(1)$. https://perpajakan.studentjournal.ub. ac.id

Rusmahafi, F. Kamalia. (2011). Kontribusi Ekspor Impor terhadap Penerimaan Negara dalam Perspektif Ekonomi Islam (Studi Empiris Indonesia dan Arab Saudi). Jakarta: UIN Syarif Hidayatullah.

Sari, A. M. Dian. (2016). Analisis Pengaruh Konsumsi Rokok terhadap Kemiskinan di Provinsi Jawa Tengah. https://lib.unnes.ac.id/24966/1/71114 12074.pdf

Sari, D. P. (2019). "Analisis Perbedaan Penerimaan Pajak Sebelum dan Sesudah Penerapan Program Pengampunan Pajak (Tax Amnesty) Pada KPP Pratama Denpasar.” Jurnal Sains, Akuntansi Dan Manajemen, 1(1), 1-34.

SEF. (2017). Pajak dan Bea Cukai dalam Perspektif Islam. SEF UGM. https://sef.feb.ugm.ac.id/pajak-danbea-cukai-dalam-perspektif-islam/

Setiawan, S. R. Diah. (2020). Kinerja Industri Menurun akibat Corona, Bagaimana Kenaikan Cukai Rokok? https://money.kompas.com/read/202 0/08/11/214245026/kinerja-industrimenurun-akibat-corona-bagaimanakenaikan-cukai-rokok? page $=$ all.

Suryanto, Venny., \& Dewi, H. Kartika. (2020). Relaksasi penundaan pembayaran pita cukai tembakau diwacanakan masuk program PEN 2021.

https://nasional.kontan.co.id/news/re laksasi-penundaan-pembayaran-pitacukai-tembakau-diwacanakanmasuk-program-pen-2021

Triono, Doni. (2017). Analisis Dampak Tarif Cukai Hasil Tembakau terhadap Penerimaan Negara dan Produksi Tembakau Domestik. Jurnal Pajak Indonesia, 1(1), 124-129.

WHO. (2010). WHO technical manual on tobacco tax administration. https://www.who.int/tobacco/publica tions/tax_administration/en/

Wicaksono, Adhi. (2020). Penerimaan Cukai Rokok 2020 Diprediksi Shortfall Rpl,37 T. https://www.cnnindonesia.com/ekon omi/20200721182115-532527293/penerimaan-cukai-rokok2020-diprediksi-shortfall-rp137-t 